\title{
USE OF LATERITIC SOIL AMENDED WITH BENTONITE AS LANDFILL LINER
}

\author{
Nithi S. Thankam ${ }^{1}$, Rekha V. ${ }^{2}$ and Uma Shankar ${ }^{3, *}$ \\ ${ }^{1}$ Department of Civil Engineering, VIT University, Vellore-632014, Tamil Nadu, India \\ ${ }^{2}$ Department of Zoology DKM College for Women, Vellore-632001, Tamil Nadu, India \\ ${ }^{3}$ Department of Civil Engineering, VIT University, Vellore-632014, Tamil Nadu, India \\ *E-mail : mumashankar@vit.ac.in
}

\begin{abstract}
The main objective of this study is to find the usefulness of laterite soil amended with bentonite as liners in landfills. The minimum requirement of a liner for landfill is it should have a hydraulic conductivity less than $10^{-7} \mathrm{~cm} / \mathrm{sec}$. Various proportions of lateritic soil blended with bentonite have been tested to suggest a suitable liner. This paper presents experimental results obtained on hydraulic conductivity of lateritic soil blended with bentonite. Bentonite content in the blend is varied as $0 \%, 10 \%, 20 \%$ and $30 \%$ to the dry weight of lateritic soil. The solute concentration used are Deionised water, $5 \mathrm{mM}$ of $\mathrm{K}_{2} \mathrm{Cr}_{2} \mathrm{O}_{7} 0.5 \mathrm{M}$ of $\mathrm{CaCl}_{2}$ and $0.5 \mathrm{M}$ of $\mathrm{NaCl}$. Hydraulic conductivity value decreased from $7.18 \times 10^{-7} \mathrm{~cm} / \mathrm{s}$ to $1.894 \times 10^{-8} \mathrm{~cm} / \mathrm{s}$ when permeated with deionized water (DIW) when bentonite content was varied from 0 to $30 \%$. When $5 \mathrm{mM}$ of $\mathrm{K}_{2} \mathrm{Cr}_{2} \mathrm{O}_{7}$ is used as a solute $\mathrm{k}$ value decreases with increase in bentonite content as the precipitate formed clogs the pores in the sample. Similar results were obtained with $0.5 \mathrm{M}$ $\mathrm{CaCl}_{2}$ and $0.5 \mathrm{M}$ of $\mathrm{NaCl}$. Of all the blend $80 \%-20 \%$ laterite-bentonite blend is found as the best material to be used as liner in a landfill
\end{abstract}

Keywords: Landfill liners, hydraulic conductivity, deionized water, bentonite, lateritic soil

(C) RASĀYAN. All rights reserved

\section{INTRODUCTION}

Open dumping is the most practiced way of municipal solid waste (MSW) disposal. More than $250 \mathrm{MT}$ of wastes are found disposed of in many dump yards ${ }^{1}$. It comprises wastes of different characteristics including industrial, chemical, biological and biomedical wastes ${ }^{2}$. Many of them have the presence of heavy metals like chromium, nickel, zinc, lead, cadmium etc. ${ }^{3}$. The leachates generated from them again worsen the situation by contaminating the groundwater. A long-term exposure to the contaminated environment can affect $1 / 4^{\text {th }}$ of the total population exposed to it adversely according to $\mathrm{WHO}^{4}$. So to maintain the safety of the ecological environment it is necessary to construct landfills, to contain the generated leachate and prevention of contamination of groundwater, whose main components are a barrier called liner, a cover and the deposited waste ${ }^{5}$.

Liners are made of different materials viz., compacted clay liners (CCL), geomembranes, geosynthetic clay liners (GCL), asphalt clay liners (ACL).Hydraulic conductivity is the most important parameter which determines the selection of a suitable material for the liner ${ }^{6,7,8,9}$.

Since the use of synthetic liners like GCL makes the construction process very expensive ${ }^{10}$, the current study is conducted using different proportions of laterite-bentonite soil blend with high laterite and low bentonite percentage is suggested because of the easy availability of laterite making the soil blend one of the cheapest materials to be made useful as a liner. The low hydraulic conductivity of laterite soil makes it suitable for the construction of landfill liners ${ }^{11}$.

The property of bentonite to reduce the mix's hydraulic conductivity and improve its sorption capacity when blended with natural soils ${ }^{12-15}$ suggests it as a suitable material for landfill liners. The leachate characteristics are one important thing for consideration in the selection of a suitable proportion of the mix. The mix giving the highest adsorption of the leachate is suggested as the liner material. 


\section{EXPERIMENTAL}

Bentonite is an adsorbent aluminium phyllosilicate clay consisting mostly of montmorillonite. It has a high swell index which gives it a low permeability. Due to its low permeability, bentonite is considered for this study.

Lateritic soils constitute an important group of soils of one of the coastal districts of India. The hydraulic conductivity of lateritic soil, when permeated with heavy metal contaminated leachate, was found to be equal to $4.96910^{-7} \mathrm{~cm} / \mathrm{s}$. The lateritic soil which was used for simulating field soil was collected at a depth of $1 \mathrm{~m}$ from ground level at Vellore, TN, India. It was non-plastic and clayey silt with symbol NP according to USCS classification system. In order to maintain the consistency of the soil and to ensure proper blending of soil with bentonite, the soil is sieved through a $4.75 \mathrm{~mm}$ sieve. Table- 1 and 2 show physical properties of Bentonite and Lateritic soil.

Table-1: Physical Properties of Bentonite

\begin{tabular}{c|c}
\hline Property & Bentonite \\
\hline Specific Gravity & 2.77 \\
\hline Liquid limit(\%) & 310 \\
\hline Plastic limit(\%) & 49 \\
\hline Plasticity Index(\%) & 261 \\
\hline
\end{tabular}

Table-2: Properties of lateritic soil

\begin{tabular}{c|c}
\hline Property & Lateritic soil \\
\hline Specific Gravity & 2.32 \\
\hline Liquid Limit (\%) & - \\
\hline Plastic Limit $(\%)$ & - \\
\hline Plasticity Index $(\%)$ & - \\
\hline Gravel \%( $>4.75 \mathrm{~mm})$ & 0 \\
\hline Sand\%(4.75 mm- \\
$0.075 \mathrm{~mm})$ & 60.5 \\
\hline Silt\%(0.075 mm) & 30.5 \\
\hline Clay\%(<0.002 mm) & 9 \\
\hline Classification(uscs) & $\mathrm{NP}$ \\
\hline Free Swell Index, FSI $(\%)$ & - \\
\hline
\end{tabular}

Deionised water used to pass through the blend to calculate its permeability.

$\mathbf{K}_{2} \mathrm{Cr}_{2} \mathrm{O}_{7}: 5 \mathrm{mM} \mathrm{K}_{2} \mathrm{Cr}_{2} \mathrm{O}_{7}$ is prepared by mixing $1.47 \mathrm{~g}$ of $\mathrm{K}_{2} \mathrm{Cr}_{2} \mathrm{O}_{7}$ with 1 litre of deionized water. This solution is then passed through the sample. $\mathrm{K}_{2} \mathrm{Cr}_{2} \mathrm{O}_{7}$ is highly dangerous for human consumption. To showcase the worst case scenario $\mathrm{K}_{2} \mathrm{Cr}_{2} \mathrm{O}_{7}$ is considered for the experiment.

$\mathbf{C a C l}_{2}: 0.5 \mathrm{M} \mathrm{CaCl}_{2}$ is prepared by mixing $55.492 \mathrm{~g}$ of $\mathrm{CaCl}_{2}$ with 1 litre of deionized water. This solution is then passed through the sample as a permeant fluid used in hydraulic conductivity test.

NaCl: $0.5 \mathrm{M} \mathrm{NaCl}$ solution is prepared by mixing $29.22 \mathrm{~g}$ of $\mathrm{NaCl}$ with 1 litre of deionized water which is used as one of the permeant fluids for the hydraulic conductivity test.

\section{Compaction Test}

Compaction test is performed by Standard Proctor test (ASTM 2000, D698A) to find the optimum moisture content (OMC) and the maximum dry density (MDD) of the soil mixes of $90 \%-10 \%, 80 \%-20 \%$ and $70 \%-30 \%$ of laterite-bentonite blends and $100 \%$ lateritic soil for comparison purpose. 


\section{Hydraulic Conductivity Test}

Hydraulic conductivity of the $100 \%$ lateritic soil and the $90 \%-10 \%, 80 \%-20 \%$ and $70 \%-30 \%$ lateritebentonite blends are found out by falling head permeameter according to ASTM D2434. The soil and the blends are prepared by mixing thoroughly with their corresponding OMC and MDD and the test is conducted using deionized water (DIW), $\mathrm{K}_{2} \mathrm{Cr}_{2} \mathrm{O}_{7}, \mathrm{CaCl}_{2}$ and $\mathrm{NaCl}$ as the permeating fluids and how the soil and the blends react with different chemicals are observed.

\section{Leachate Characteristic Test}

This test is to find the heavy metal absorbance of the soil mix. There is every possibility of generation of heavy metal containing leachates from various sources wastes. Though the adopted laterite-bentonite mix proportion gives a very less permeability value there are chances of some fluid being permeated through the liner. So it is important to find how much the liner is able to absorb the concentration of the heavy metal presence in the generated leachate. In this test, a solution of $5 \mathrm{mM} \mathrm{K} \mathrm{Kr}_{2} \mathrm{O}_{7}$ is prepared and is a solution is allowed to pass through the soil mix. A sample of the resulting leachate generated is taken and tested in UV-spectrometer to get the absorbance value and its corresponding concentration. The absorbance value shows how much concentration of the applied solution is being absorbed by the liner material.

\section{RESULTS AND DISCUSSION}

Figures- 1, 2, 3 and 4 show the variation of water content and dry densities obtained for $100 \%-0 \%, 90 \%$ $10 \%, 80 \%-10 \%$ laterite-bentonite blends. From each graph, the OMC and MDD of the different mixes are obtained. Table-3 makes it clearly understood that as the percentage of bentonite is increased the OMC is also increased and the corresponding MDD is decreased.

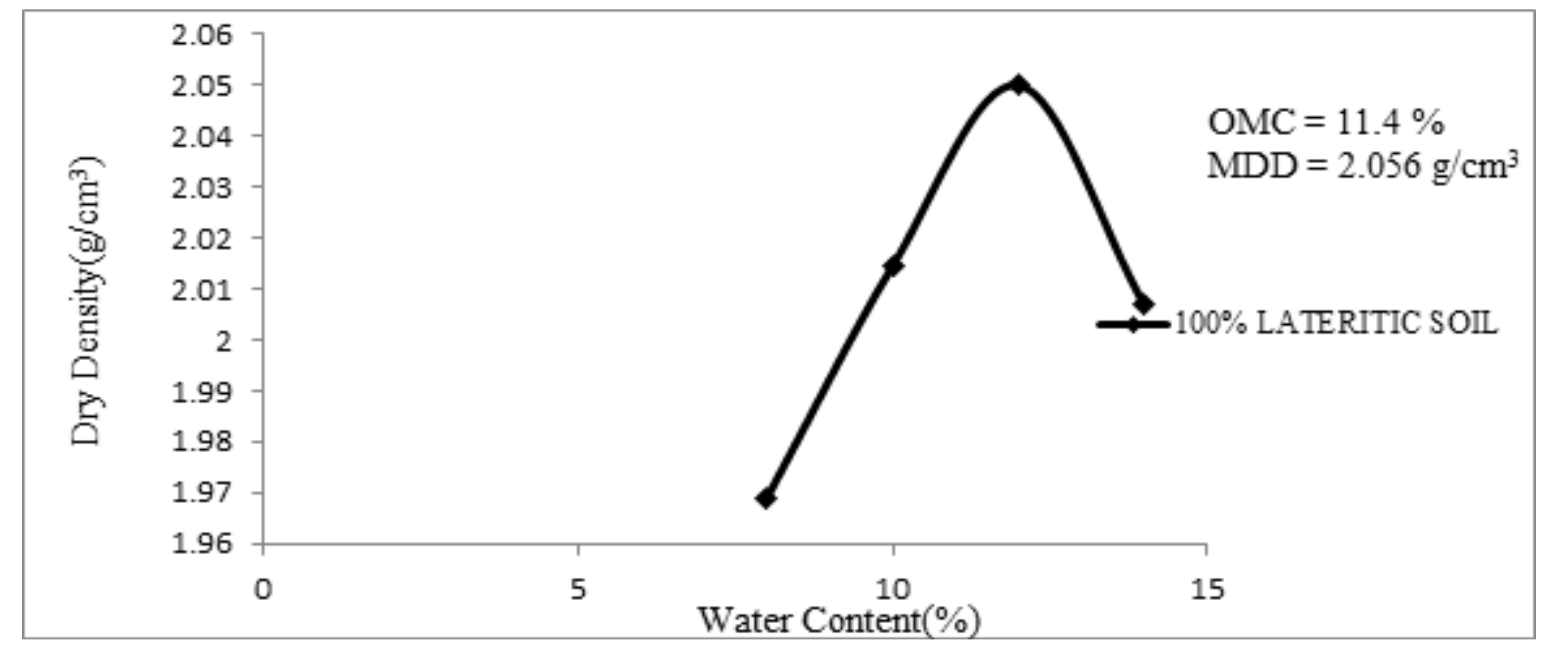

Fig.-1: Variation of dry density with water content on $100 \%$ lateritic soil

Table-3: Maximum Dry Density and Optimum Moisture Content

\begin{tabular}{c|c|c}
\hline $\begin{array}{c}\text { LATERITE-BENTONITE } \\
\text { MIX }\end{array}$ & $\begin{array}{l}\text { MDD } \\
(\mathrm{g} / \mathrm{cc})\end{array}$ & $\begin{array}{c}\text { OMC } \\
(\%)\end{array}$ \\
\hline $100 \%$ LATERITE & 2.056 & 11.4 \\
\hline $90 \%-10 \%$ & 2.072 & 11.5 \\
\hline $80 \%-20 \%$ & 2.032 & 12 \\
\hline $70 \%-30 \%$ & 2.026 & 12.5 \\
\hline
\end{tabular}


RASĀYAN J. Chem.

Vol. 10 | No. 4 |1431-1438 | October - December | 2017

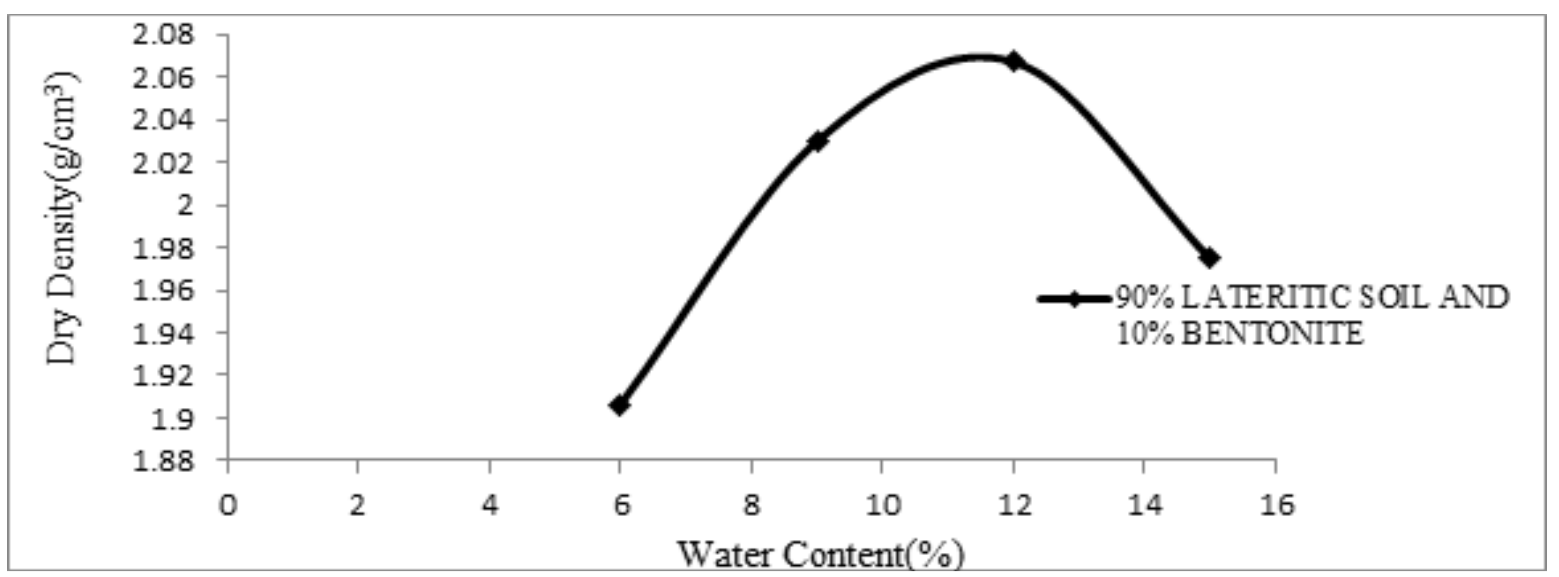

Fig.-2: Variation of dry density with water content on $90 \%-10 \%$ laterite-bentonite blend

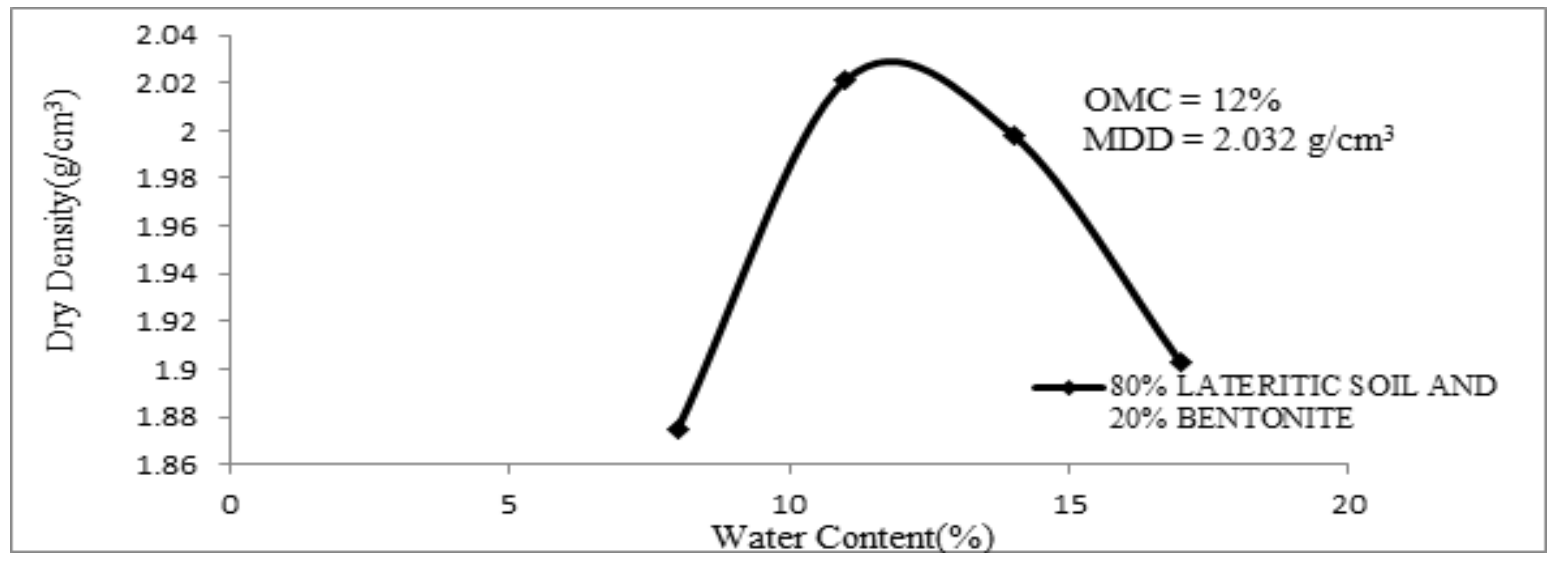

Fig.-3: Variation of dry density with water content on $80 \%-20 \%$ laterite-bentonite blend

Figures-5, 6, 7 and 8 show the variation of hydraulic conductivity in different soil mixes when permeated with DIW, $\mathrm{K}_{2} \mathrm{Cr}_{2} \mathrm{O}_{7}, \mathrm{CaCl}_{2}$ and $\mathrm{NaCl}$ respectively. In all the 4 graphs it is clearly understood that as the bentonite amount is increased in the mixes the hydraulic conductivity gets reduced. For $80 \%-20 \%$ and $70 \%-30 \%$ mixes the $\mathrm{k}$ is consistent. Since bentonite is a smectic soil with very high free swell index, it is not advisable to use it in a very high proportion in the soil blend. Considering all these and in an economical point of view, $80 \%-20 \%$ laterite-bentonite mix is the most suitable among all the mixes tested.

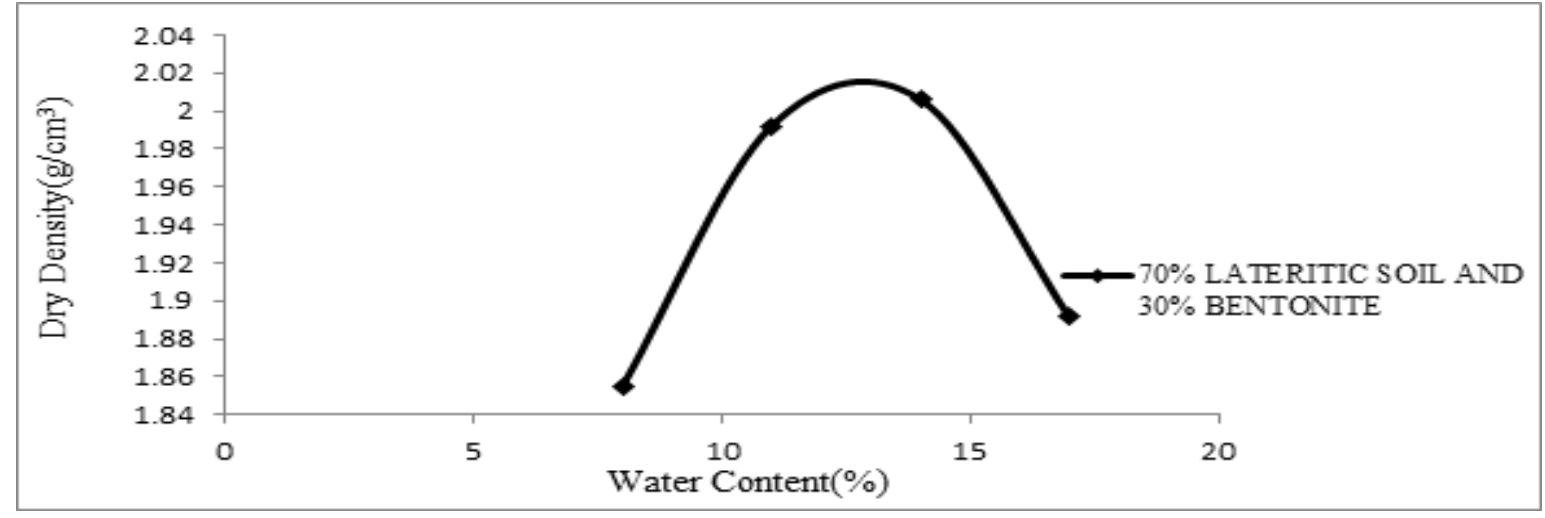

Fig.-4: Variation of dry density with water content on 70\%-30\% laterite-bentonite blend 
RASĀYAN $J$. Chem.

Vol. 10 | No. 4 |1431-1438 | October - December | 2017

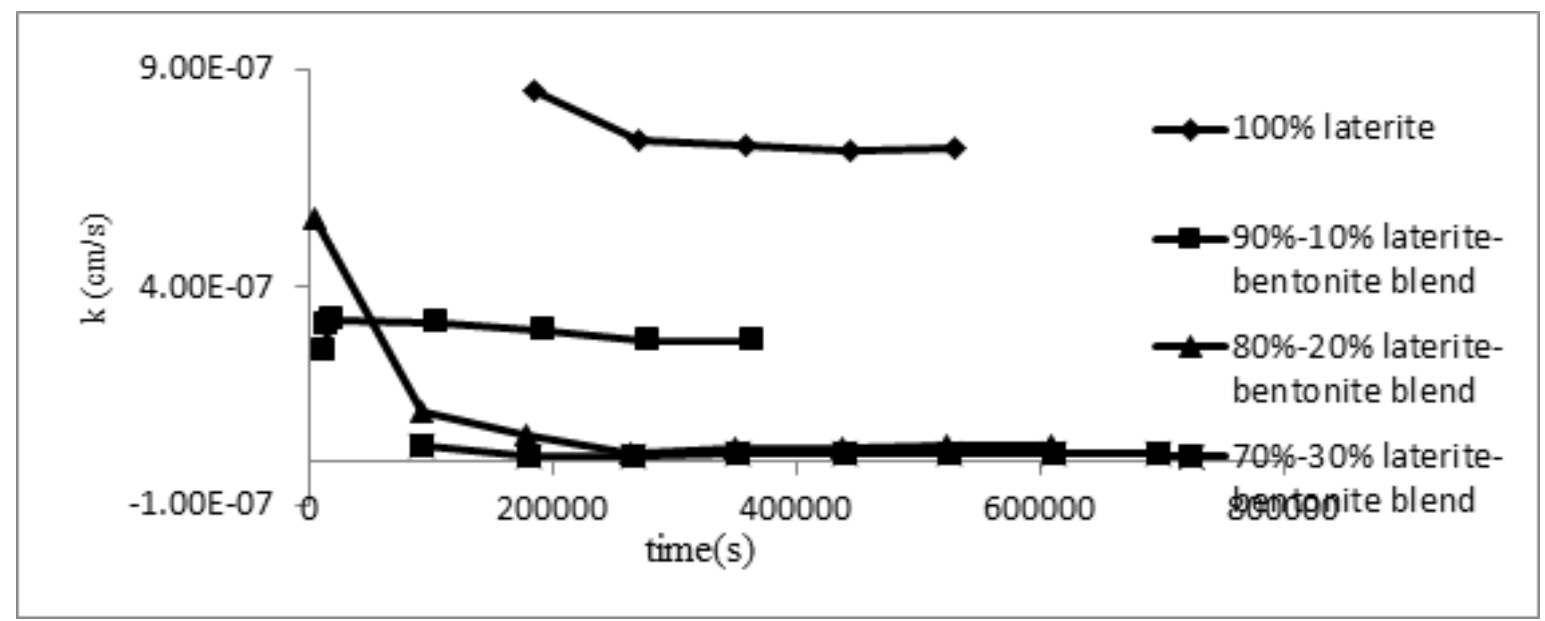

Fig.-5: Variation of hydraulic conductivity with DIW

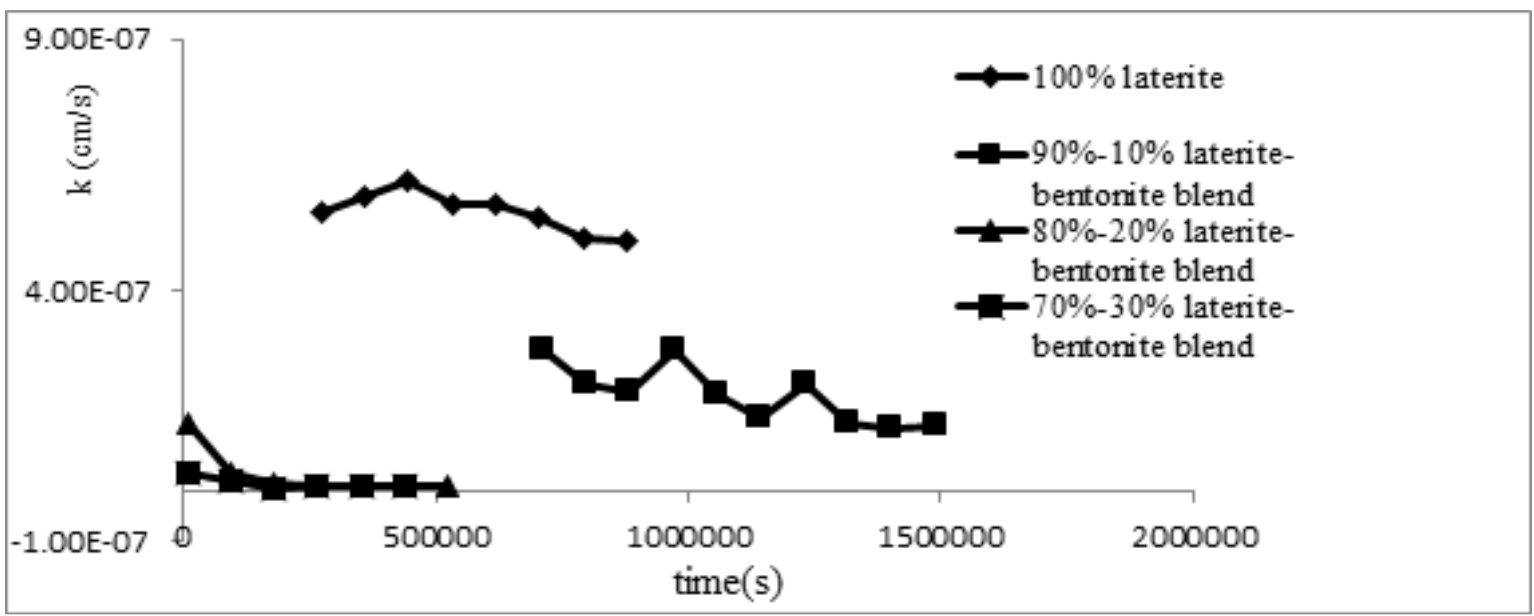

Fig.-6: Variation of hydraulic conductivity with $\mathrm{K}_{2} \mathrm{Cr}_{2} \mathrm{O}_{7}$

Figure-9 is the standard graph plot between concentration and absorbance of the standard stock solutions prepared with concentrations $5 \mathrm{ppm}, 10 \mathrm{ppm}, 15 \mathrm{ppm}$ and $20 \mathrm{ppm}$. From which the equation connecting the two variables is obtained.

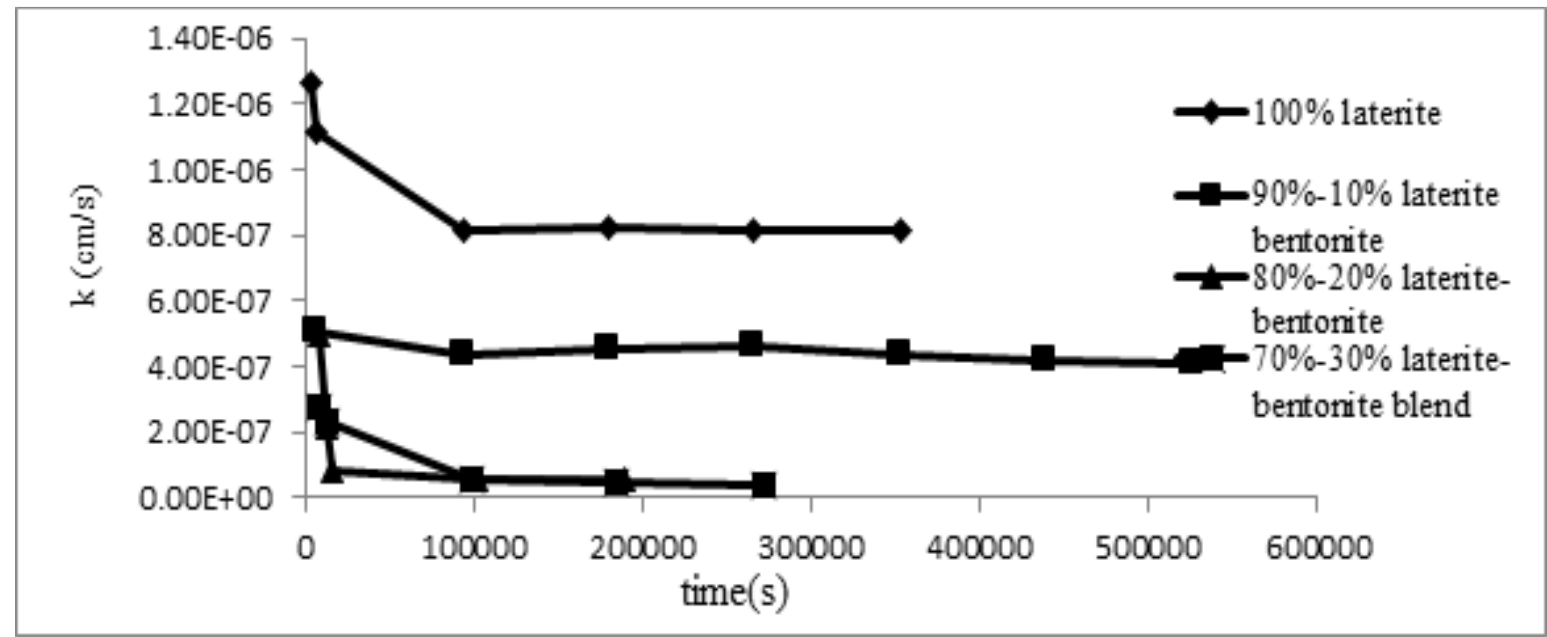

Fig.7: Variation of hydraulic conductivity with $\mathrm{CaCl}_{2}$ 
RASĀYAN J. Chem.

Vol. 10 | No. 4 |1431-1438 | October - December | 2017

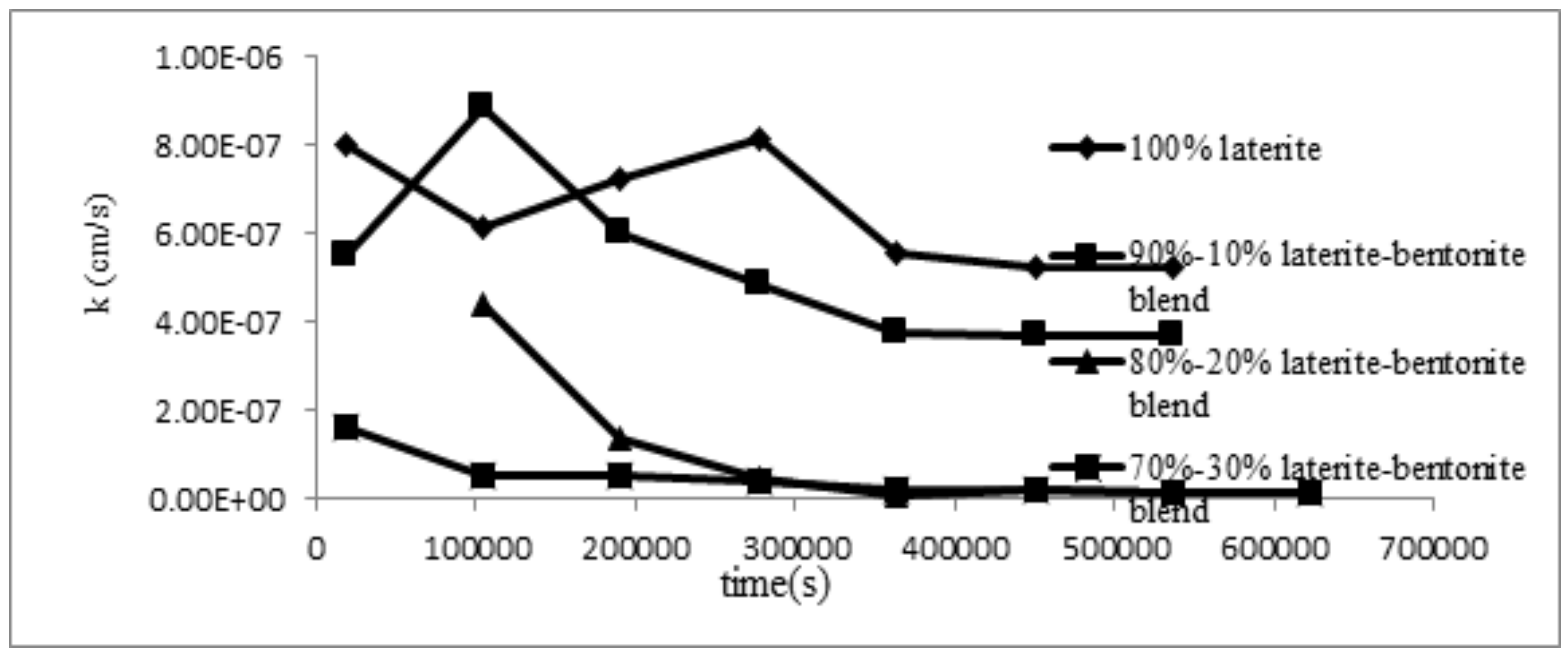

Fig.8: Variation of hydraulic conductivity with $\mathrm{NaCl}$

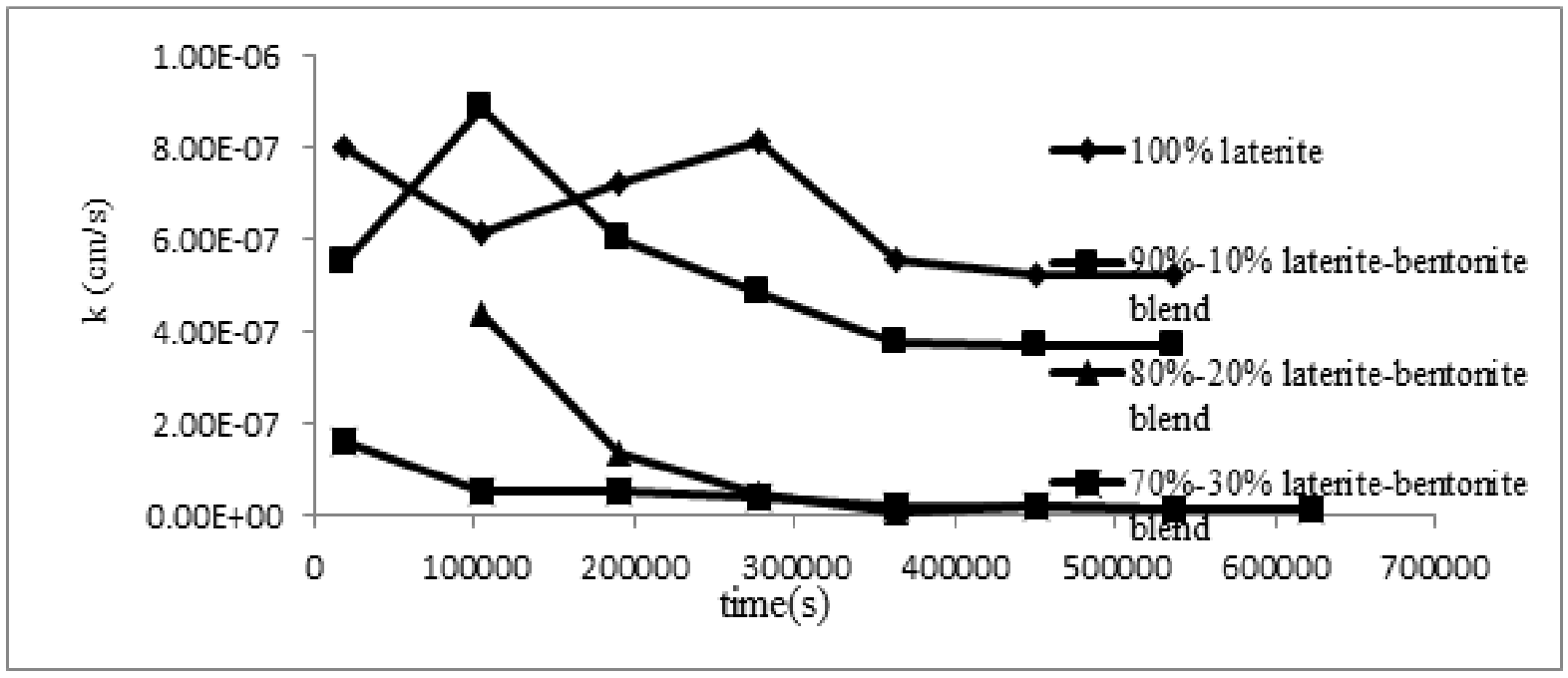

Fig.-9: Standard graph for concentration and absorbance

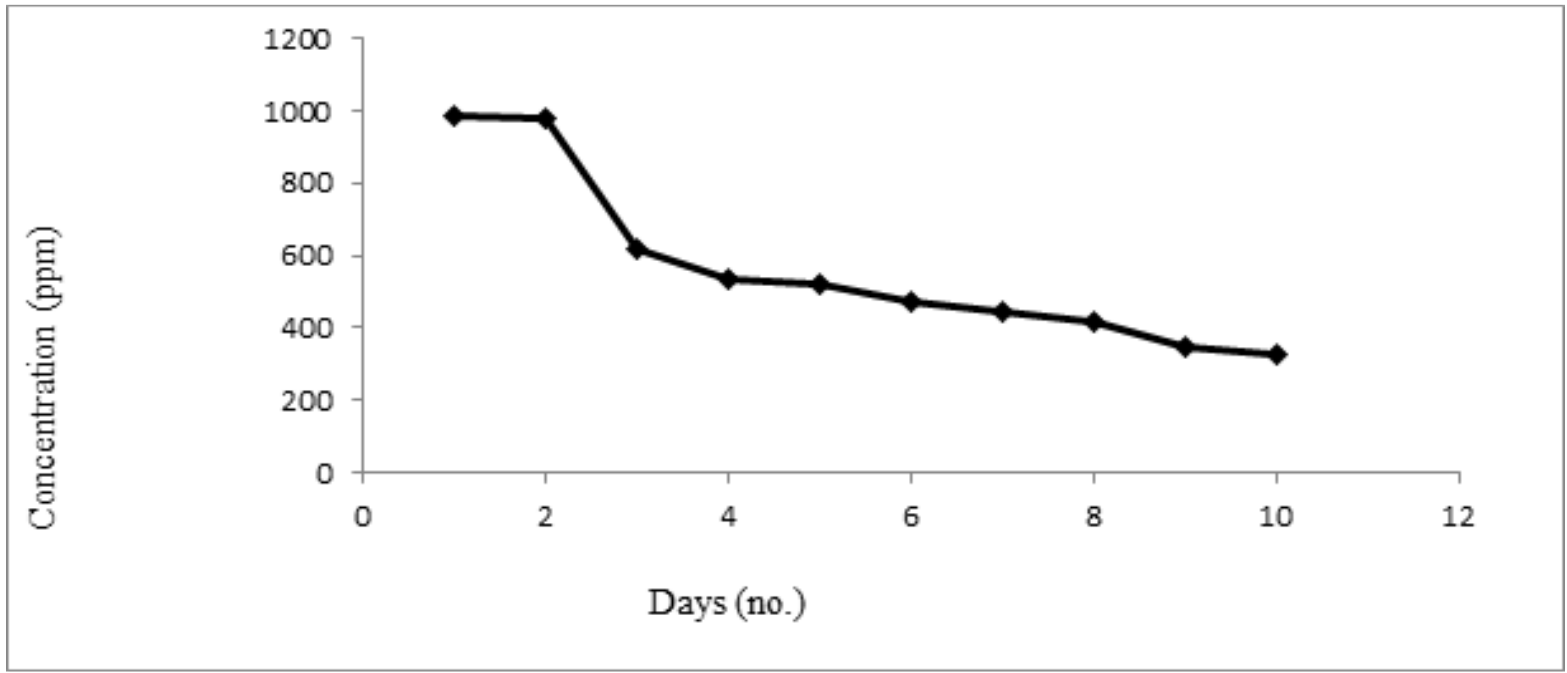

Fig.-10: Variation of absorbance with days for $90 \%-10 \%$ laterite-bentonite blend 
RASĀYAN J. Chem.

Vol. 10 | No. 4 |1431-1438 | October - December | 2017

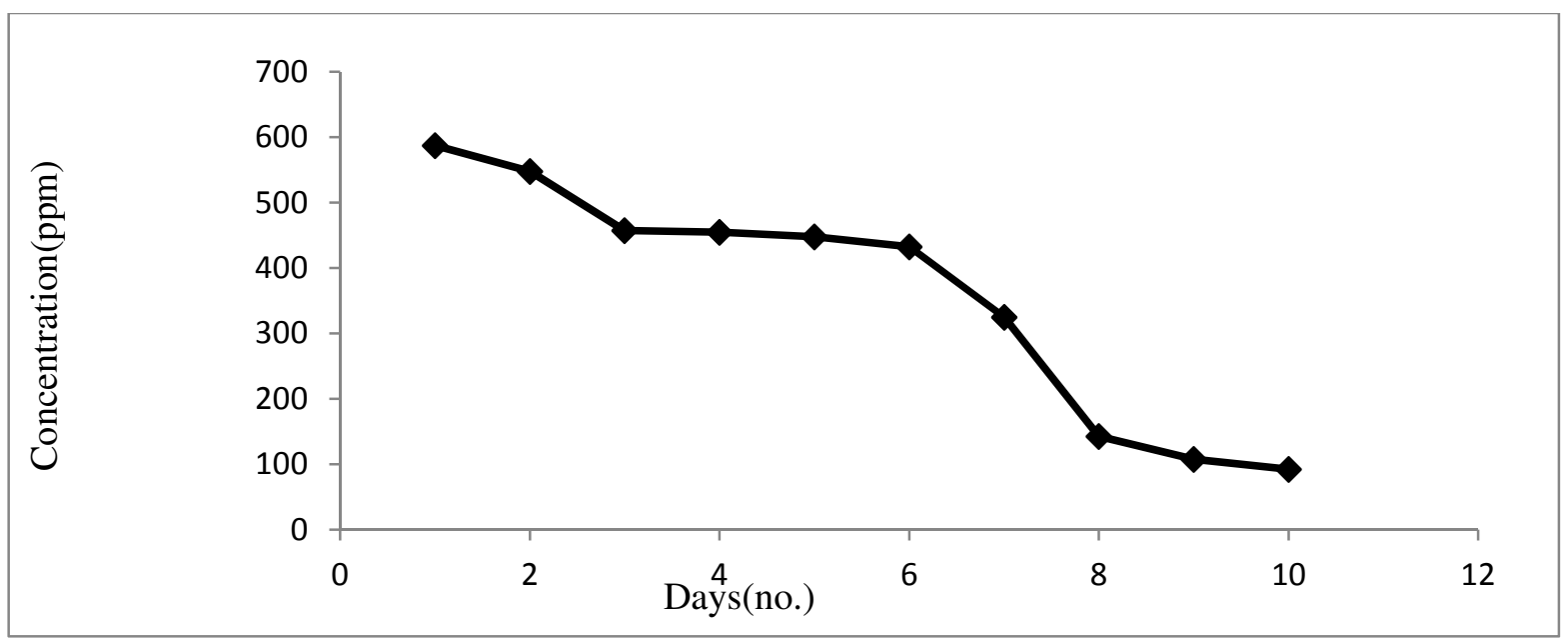

Fig.-11: Variation of absorbance with days for $80 \%-20 \%$ laterite-bentonite blend

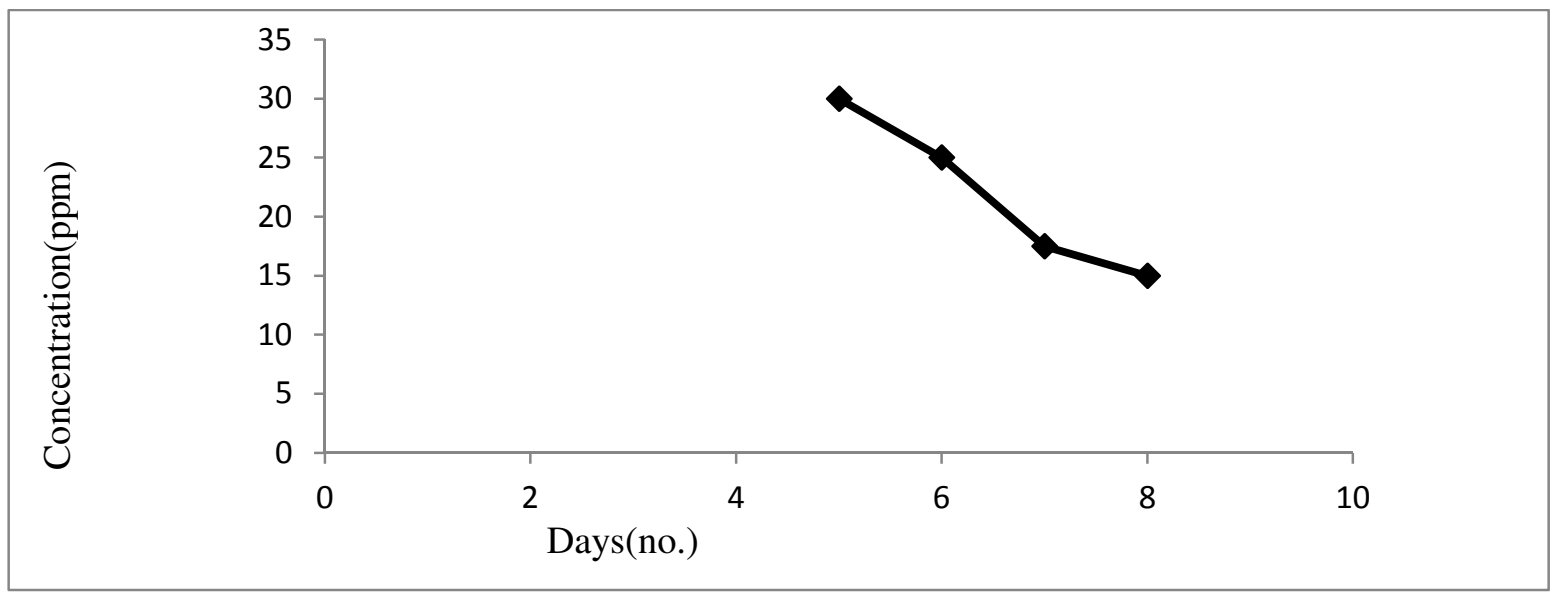

Fig.-12: Variation of concentration with days for 70\%-30\% laterite-bentonite blend

Figures-10, 11 and 12 graphs show the variation of concentrations obtained for different soil mixes with days. $5 \mathrm{mM} \mathrm{K} 2 \mathrm{Cr} 2 \mathrm{O} 7$ is used to generate the leachate artificially and at the end of each day the collected leachate is tested in UV Spectrometer. As 100\% lateritic soil couldn't retain the solution applied for more than 2 hours, the test proceeds with 90\%-10\%, 80\%-20\% and 70\%-30\% laterite-bentonite mix. 90\%-10\% mix gave a retention of $77.89 \%$ concentration whereas $80 \%-20 \%$ gave $93.7 \%$ and $70 \%-30 \%$ gave $98.97 \%$ retention of the concentration.

\section{CONCLUSION}

From the study conducted on laterite and laterite-bentonite mixes, a lot of observations can be made right from the standard proctor test to the hydraulic conductivity test to the leachate characteristic test. From the SPT, the variation in the OMC value with the variation in the amount of bentonite in the lateritebentonite mixes shows that as the amount of bentonite in the soil mix increases the OMC is getting increased. For $10 \%$ bentonite and the remaining lateritic soil the OMC obtained is $11.5 \%$ with an MDD of $2.072 \mathrm{~g} / \mathrm{cc}$, for $20 \%$ bentonite and $80 \%$ laterite mix the OMC got up to $12 \%$ with an MDD of $2.032 \mathrm{~g} / \mathrm{cc}$ and finally for 70\%-30\% mix OMC goes to $12 \%$ with an MDD of $2.026 \mathrm{~g} / \mathrm{cc}$. From all these, it can be concluded that as a number of bentonite increases in the mix OMC increases and the corresponding MDD decreases. From the hydraulic conductivity tests done on different soil mixes the best soil mix is found to be (80\%-20\%) laterite-bentonite mix for all the permeating fluids done, including deionized water and the inorganic acidic solution like $\mathrm{K}_{2} \mathrm{Cr}_{2} \mathrm{O}_{7}$ and inorganic salt solutions like $\mathrm{CaCl}_{2}$ and $\mathrm{NaCl}$ since the $\mathrm{k}$ for $(80 \%-20 \%)$ is consistent with that of $(70 \%-30 \%)$ mix and the coefficient of hydraulic conductivity is well 
RASĀYAN J. Chem.

Vol. 10 | No. 4 |1431-1438 | October - December | 2017

within the standard regulatory value of $10^{-7} \mathrm{~cm} / \mathrm{s}$. And among the four permeating fluids used $\mathrm{CaCl}_{2}$ shows the highest hydraulic conductivity followed by deionized water, then by $\mathrm{NaCl}$ and $\mathrm{K}_{2} \mathrm{Cr}_{2} \mathrm{O}_{7}$. $\mathrm{K}_{2} \mathrm{Cr}_{2} \mathrm{O}_{7}$ gives the least $\mathrm{k}$ since the solution produces precipitates which clogs the pores in the soil not allowing the fluid to pass through the soil mix easily. Due to its greatest cation exchange capacity compared to DIW and $\mathrm{NaCl}, \mathrm{CaCl}_{2}$ can easily pass through the solution resulting in a higher permeability than even the deionized water.

\section{REFERENCES}

1. R. Ravishankar, B. Madhuri, Gopal Mugeraya, NITK Research Bulletin 14(1), 20(2004).

2. Sitaram Nayak, B.M. Sunil, S. Srihari, Journal of Engineering Geology, 23, 137(2007)

3. Tanit Chalermyanont, Surapon Arrykul, Nanthanit Charoenthaisong, Journal of Waste Management, 29, 117(2009).

4. N.G. Kimani, Environmental Pollution and Impact to Public Health; Implication of the Dandora Municipal Dumping Site in Nairobi, Kenya. UNEP, Nairobi, Kenya, 40 (2007).

5. D.E. Daniel,Geotechnical Practice for Waste Disposal, Chapman and Hall, London, 683(1993).

6. P.V. Sivapullaiah, A. Sridharan, V.K. Stalin, Canadian Geotechnical Journal, 37(2), 406(2000).

7. Kolawole J. Osinubi and Adrian O. Eberemir Int. Jrl of Environment and Waste Management, 11(1) 38(2013).

8. D.E. Daniel and C.H. Benson, J. Geotechnical Engrg., ASCE, 116 (12), 1811(1990).

9. I. Borgadi, W.E.Kelly and X. Wang, Journal of Geotechnical and Geoenvironmental Engineering, ASCE, 115(5), 658(1989).

10. E. Cokca and Z. Yilmaz, Waste Management, 24(2), 153(2004).

11. D.E. Daniel and C.H. Benson, J. Geotechnical Engg., ASCE, 116(12), 1811(1990).

12. G.A. Eklund, Laboratory comparison of the effects of water and waste leachate on the performance in soil liners. Hydraulic Barriers in soil and rock, 188-202(1985).

13. C.D. Shackelford, C.H. Benson, T. Katsumi, T.B. Edil and L. Lin, Geotextiles and Geomembranes, Elsevier Science, 18,133(2000).

14. D. Koch, Applied Clay Science. 21,1(2002).

15. D.A. Laird, Applied Clay Science, 34, 74(2006).

[RJC-1818/2017] 